PAX ROMANA 



\section{Paul Petit}

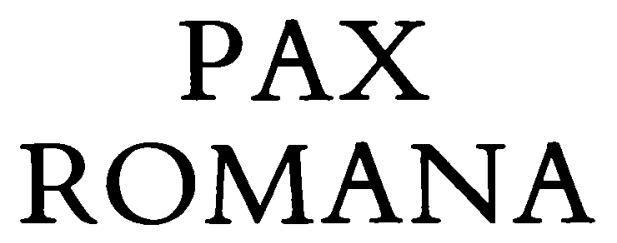

translated by James Willis

University of California Press Berkeley and Los Angeles 
First English language edition 1976

Originally published in France as

La Paix Romaine

by Presses Universitaires de France, Paris, I 967

(C) Paul Petit, 1967

\author{
Printed in Great Britain \\ for the publishers \\ University of California Press \\ Berkeley and Los Angeles, California \\ ISBN: 0-520-02I 7I-I
}

